Vol.17,No.62,January 2022, 83- 95

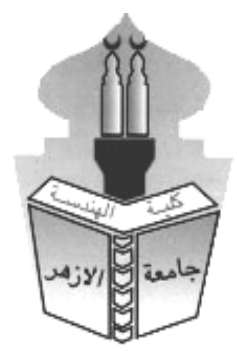

\title{
NUMERICAL VALIDATION OF MONOPILE LOADING TEST FOR WIND TURBINE FOUNDATION USING PLAXIS 3-D
}

\author{
Reham M. Younis ${ }^{1 *}$, Adel Dief ${ }^{2}$, Rami El- Sherbiny ${ }^{3}$, Waleed EL-Sekelly ${ }^{4}$ \\ 1,2,4 Structural Engineering Department, Faculty of Engineering, Mansoura University, \\ Mansoura, Egypt \\ ${ }^{3}$ Department of Public Works, Faculty of Engineering Cairo University, Giza, Egypt \\ *Corresponding Author E-mail: rehamyounis3@gmail.com.
}

Received :24 Augst. $2021 \quad$ Accepted:26 Oct. 2021

\begin{abstract}
:
This paper presents the verification of a three-dimensional finite element model of full-scale field monopile tests for offshore wind turbine foundations. The results from numerical modeling using PLAXIS 3-D are verified against previously published measured data obtained from optical fiber sensors installed on the internal steel surface of a monopile. The field tests were carried out at a wind farm $200 \mathrm{~km}$ from Shanghai and $25 \mathrm{~km}$ offshore in the East China Sea. Both vertical and horizontal pile load tests were performed separately on the top of the monopile to investigate soilpile interaction and the pile behavior for the proposed offshore wind farm. The soil is modeled using an elastic - perfectly plastic Mohr-Columb model, while the monopile is modeled using a linear elastic mode. The measured and calculated vertical and horizontal movements, and vertical and horizontal loads along the pile depth are compared. The results of the numerical analysis using the three-dimensional finite element program PLAXIS 3-D are in good agreement with the results of both vertical and horizontal pile loading stages measured from field test results, indicating that the proposed model is suitable for modeling the behavior of axially and laterally loaded monopiles.
\end{abstract}

KEYWORDS: Monopile, Simulation, Numerical modeling, PLAXIS 3-D, FLAC 3-D, Field pile load tests

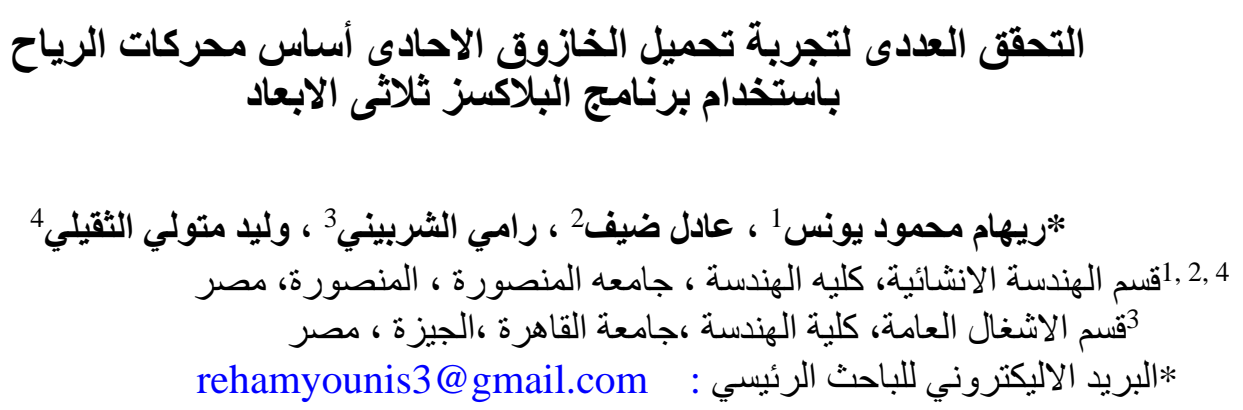
تقام هذه الورقه البحثية التحقق من نموذج ثلاثي الأبعاد للعناصر المحدودة بعمل نمذجة لاختبارات موقعية لخازوق أساسات

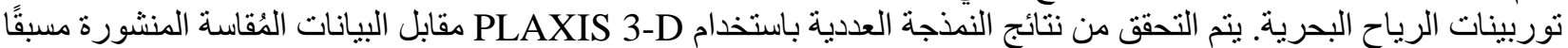
و التي تم الحصول عليها من مستشعرات الألياف الضوئية المثبتة على السطح الفولاذي الداخلي للخازوق الاحادي. وأجريت 
الاختبار ات الميدانية في مزرعة رياح على بعد 200 كيلومتر من شنغهاي و 25 كيلومتر ا قبالة بحر الصين الثرقي. تم إجر اء كل

من اختبار ات الحمل الر أسي والأفقي بشكل منفصل على الجزء العلوي من الخازوق الاحادي للتحقق من تفاعل الخازوق مع التربة

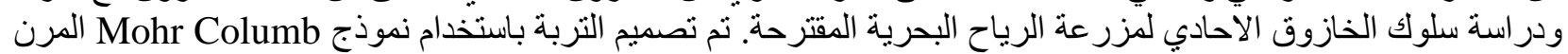

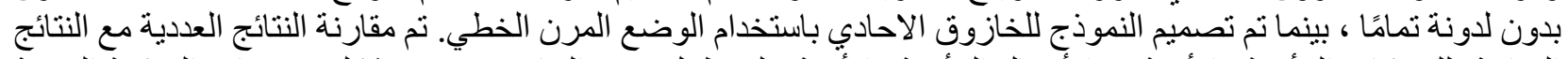

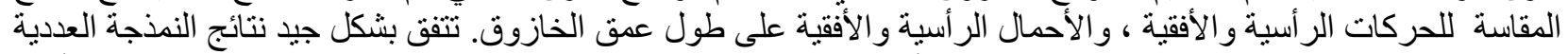

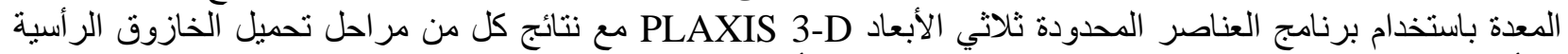

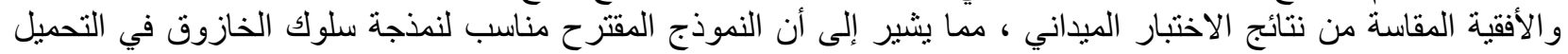

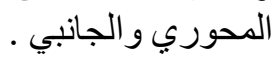

\section{INTRODUCTION}

Renewable wind power is one of the most favored alternative energy choices, especially offshore wind. The offshore wind energy sector is rapidly growing around the world. The most common foundations used for offshore wind turbines are monopiles (Malhotra 2011). Monopiles are widely used in such applications as they are easy to manufacture and transport, as compared to other types of foundation systems (Bekken 2009). Monopile is a single largediameter, thick-walled steel cylindrical tube (pile) driven into the seabed (using hammering or vibration techniques) as shown in Fig. 1, followed by a transition piece with a grouted connection that connects the pile and a tower on top of which the turbine is installed (Leite, 2015). Monopiles have been used for many years and are considered to be the most cost-effective and practical form of foundation for such application, as shown in Fig. 2 (EWEA 2015; Carswell 2012; Malhotra 2011; Bekken 2009). Its shape allows for simple calculations, easy manufacture, and secure loading on transport vessels. It's also less expensive than other types of foundations and easier to install at shallow to medium water depths( Cabral, 2015). Numerical modeling of monopiles is important in understanding the behavior of such piles and guiding their design under axial, lateral, and combined loading.
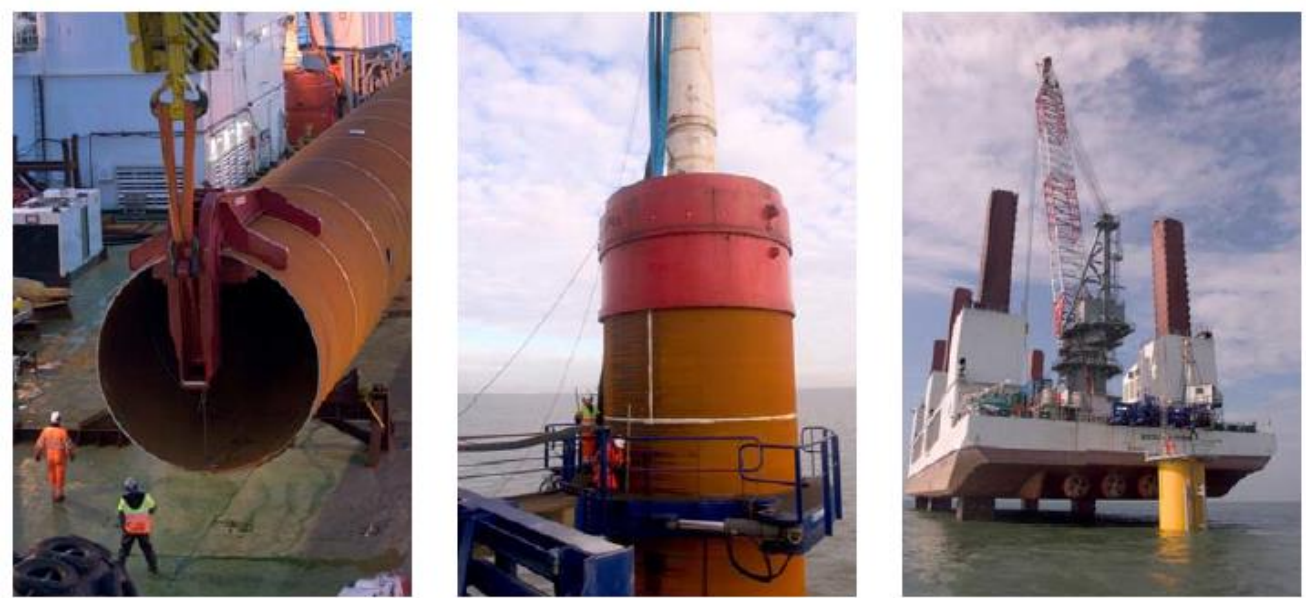

Fig. 1: Installation of the Kentish Flats offshore wind farm. (El-Marassi, 2011) 


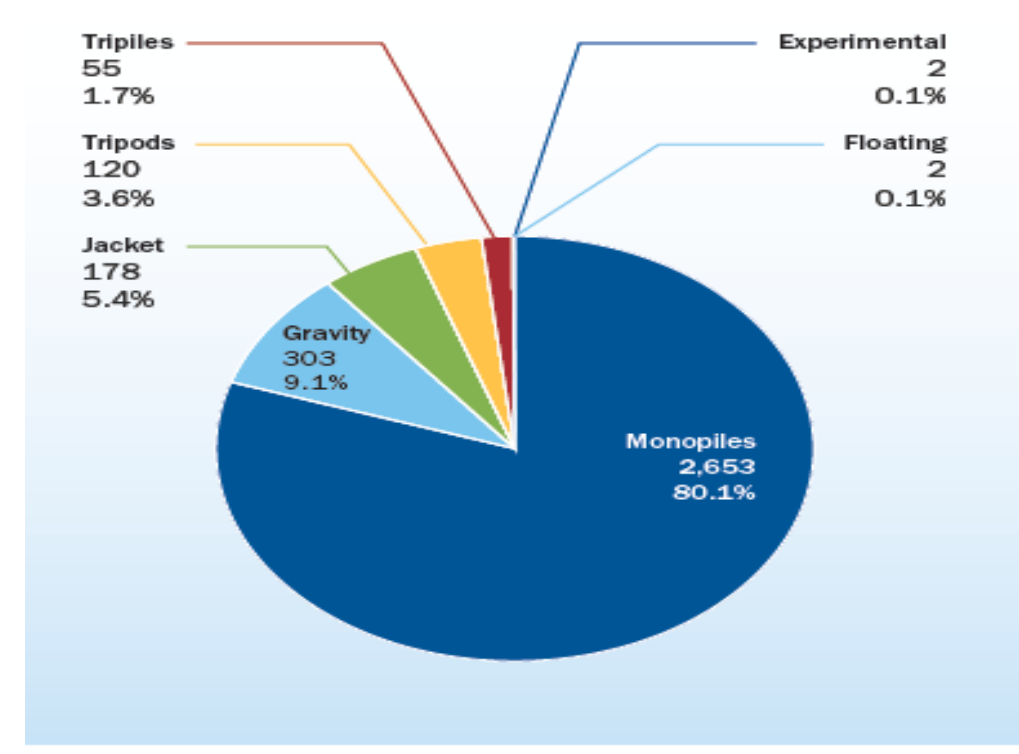

Fig. 2. Substructure types for online wind energy end of 2015 (EWEA 2015 Europe).

Pan et al. (2016) compared measured field data from axial and lateral loading of instrumented monopiles with the results of numerical modeling that was carried out using the threedimensional finite difference program FLAC 3-D. The Finite-difference program FLAC 3-D works by discretizing the domain into a grid of hexahedral cells or nodes. The solution is obtained at each nodal point. Although FDM is easy to implement and the compute time for each step is fast, the number of steps required for convergence is high (Fausett, 2003). The finite element method (FEM) discretization is based upon a piecewise representation of the solution in terms of specified basis functions. In FEM, the discretization is not restricted to a grid of hexahedral cells or nodes. Instead, a solution is approximated by using interconnecting subregions or simple geometric elements. So this flexibility in construction of elements allows us to accurately model complex geometries (Zienkiewicz et al., 1965, Tibebu, 2020).

In this study, a three-dimensional finite element model is developed for axially and laterally loaded monopiles using PLAXIS 3-D. The model is verified against the results of the field monopile tests reported by Pan et al. (2016). In addition, the results are compared with the results of the finite-difference model reported by Pan et al. (2016) using FLAC 3-D. The developed model is a useful tool for further investigating the behavior of monopiles of different configurations in response to different loading conditions.

\section{Finite Element Model}

The full scale monopile tests were modeled using a three-dimensional finite element model mimicking the test geometry and boundary conditions. The material parameters used in the

\subsection{Geometry}

The zone of study is an area of $90 \mathrm{~m}$ wide by $90 \mathrm{~m}$ long surrounding the monopile Fig. 3, which minimizes the effect of boundary conditions on the monopile model results. The soil stratigraphy is shown in Table 1 and Fig 4, which shows a schematic plot of the pile with soil layer levels as reported by Pan et al. (2016). The soil stratigraphy consists of silty clay to a depth of $25 \mathrm{~m}$ followed by layers of silty sand. The Mohr-Coulomb model, commonly used in modeling soil behavior, was found to have the ability to deliver results with sufficient accuracy and reliability while keeping the input parameters needed for the model within the range of available geotechnical measurements. The elastic-plastic Mohr-Coulomb model used takes the increase in stiffness with depth into 
account. The model requires four parameters, which are easy to obtain from basic soil sample tests. These parameters are: E, Young's modulus $\left[\mathrm{MN} / \mathrm{m}^{2}\right]$; U, the Poisson's ratio [-]; C, cohesion $\left[\mathrm{kN} / \mathrm{m}^{2}\right] ; \phi$, the friction angle $\left[{ }^{\circ}\right]$ (Brinkgreve et al., 2016). The soil parameters used in the numerical analysis based on the interpretation of the values reported by Pan et al. (2016) which are representative of the soils found offshore in the East China Sea are shown in Table 2.

Table 1: Soil stratigraphy

\begin{tabular}{|c|c|}
\hline Soil type & Top elevation (m) \\
\hline silty clay 1 & -13.5 \\
\hline silty clay_2 & -28 \\
\hline Silty sand 1 & -38.5 \\
\hline Silty sand_2 & -61.5 \\
\hline Silty sand3 & -85.5 \\
\hline
\end{tabular}

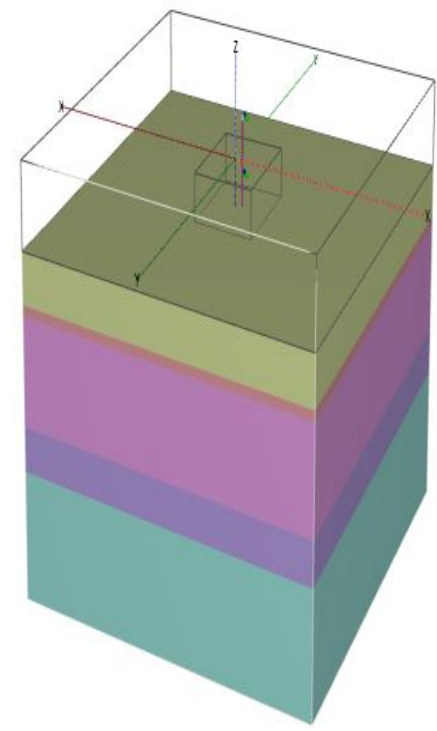

Fig. 3: geometry model of plaxis3-D

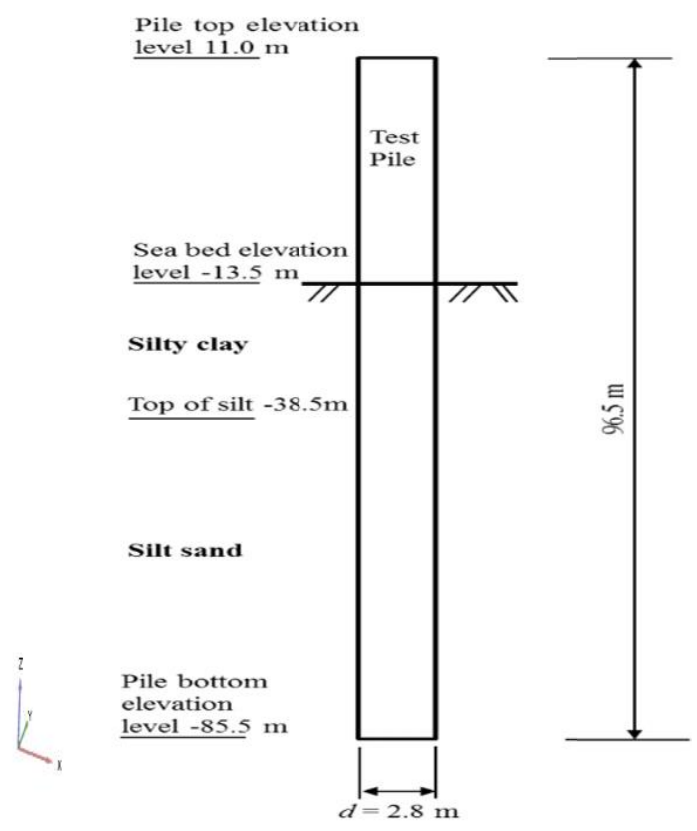

Table 2: Soil parameters for numerical back analysis Pan et al, (2016)

Hint: E max: Young's modulus of the soil for small strain $\mathrm{g}$

\begin{tabular}{|c|c|c|c|c|c|c|c|}
\hline \multirow[t]{2}{*}{ geology } & \multirow[t]{2}{*}{ Drained } & \multirow{2}{*}{$\begin{array}{l}\text { Bulk } \\
\text { unit } \\
\text { weight } \\
\left(\mathrm{kN} / \mathrm{m}^{3}\right) \\
\text { ४ }\end{array}$} & \multirow{2}{*}{$\begin{array}{l}\text { Poisson } \\
\text { ratio } \\
\mathrm{U}\end{array}$} & \multirow[t]{2}{*}{ K0 } & \multicolumn{2}{|c|}{ Drained shear strength } & \multirow{2}{*}{$\begin{array}{l}\text { Emax } \\
\text { (MPa) }\end{array}$} \\
\hline & & & & & $\varnothing\left(^{\circ}\right)$ & $\mathrm{C}(\mathrm{kPa})$ & \\
\hline Silty clay1 & Un drained $(\mathrm{A})$ & 19 & .3 & .67 & 11 & 17 & 91.3 \\
\hline Silty clay2 & Un drained (A) & 19 & .3 & .53 & 15 & 20 & 155.3 \\
\hline Silty sand1 & Drained & 19 & .35 & .39 & 33.6 & 1 & 147.3 \\
\hline Silty sand2 & Drained & 19 & .35 & .43 & 35 & 1.5 & 180.2 \\
\hline Silty sand3 & Drained & 19 & .35 & .43 & 36 & 1 & 250.5 \\
\hline
\end{tabular}

\subsection{Model and Material Properties}

The embedded pile model was used to model a structural element of a monopile with material properties shown in Table 3. The embedded pile is composed of beam elements linked with the surrounding soil by means of special interfaces (skin and foot interfaces), as shown in Fig $\mathbf{5}$. Although it does not take into account volume, a particular elastic region around the pile whose 
dimension equal to the pile diameter is assumed with plastic behavior is neglected, as shown in Fig 6. Therefore, it may be assumed that the embedded pile model acts as a simplified model of the volume pile. Although the embedded pile is a relatively new feature in PLAXIS3-D, it has been validated by comparing the volume pile with measurements from field tests (Arulanantham et al., 2015), (Dao, 2011). They found that, the embedded pile is not only in good agreement with the volume pile, but also able to resemble the real pile behavior.

Table 3: Material properties of monopile for numerical analysis

\begin{tabular}{|c|c|}
\hline Long $(\mathrm{m}) \mathrm{L}$ & 96.5 \\
\hline Free length $(\mathrm{m})$ & 24.5 \\
\hline Embedded length $(\mathrm{m})$ & 72 \\
\hline Diameter $(\mathrm{m}) \mathrm{D}$ & 2.8 \\
\hline Thickness $(\mathrm{m}) \mathrm{T}$ & .045 \\
\hline Young modulus $(\mathrm{kPa}) \mathrm{Ep}$ & $2 * 10^{8}$ \\
\hline Weight $\left(\mathrm{kN} / \mathrm{m}^{3}\right) \mathrm{\gamma s}$ & 77 \\
\hline
\end{tabular}

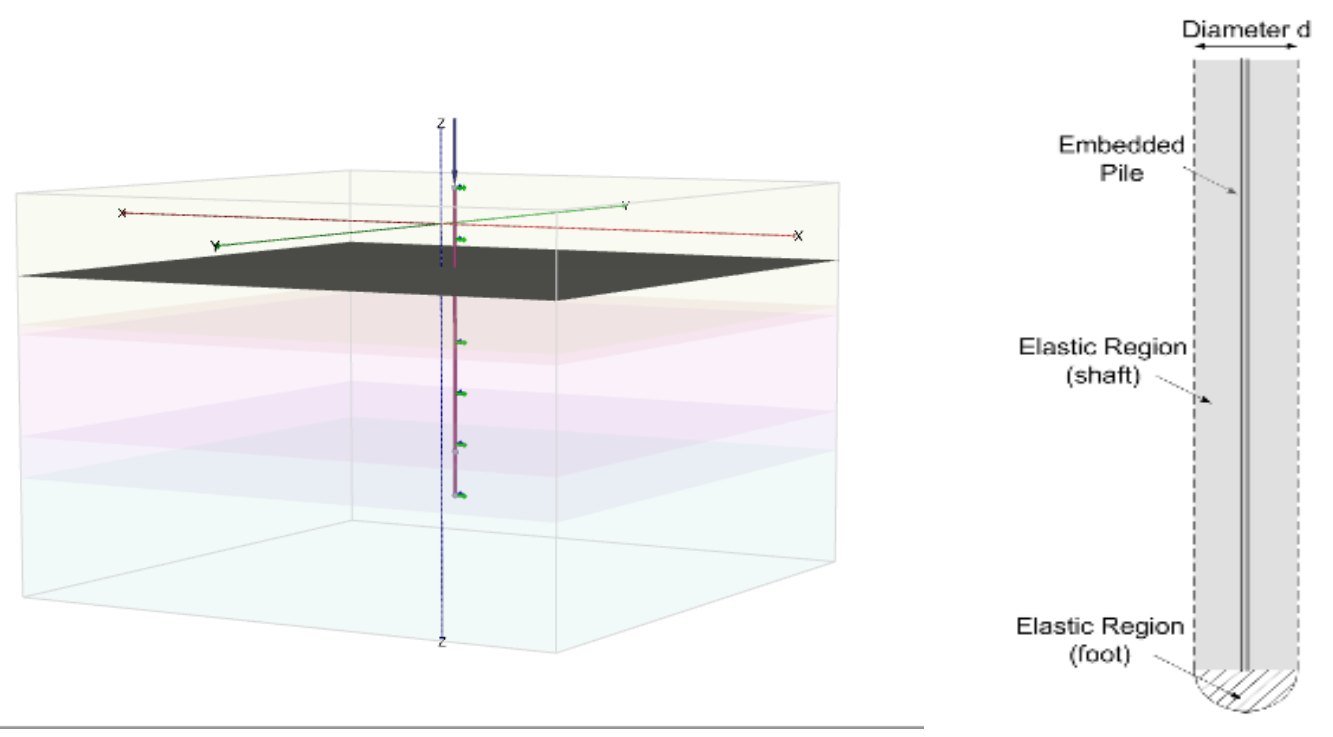

Fig. 5 Embedded pile model to simulate monopile 2.3 Initial and Boundary Conditions

Fig. 6: Elastic regions around embedded pile (Dao, 2011)

The nodes on the soil perimeter were prevented from moving in the $\mathrm{x}$ and $\mathrm{y}$-direction. The nodes on the base of the completed mesh were restrained in all three directions, while the nodes on the top face were free to move. Stresses were initialized assuming an in-situ earth pressure coefficient, k0, for clay and silt.

\subsection{Mesh Generation}

The volume surrounding the pile had a refined mesh to improve accuracy. The software first generates a 2-D mesh of work planes of the volume. The 2-D mesh was fully satisfactory (including global and local refinements) before proceeding to the 3-D mesh generation as shown in Fig 7. It is preferred to avoid very fine meshes, since this leads to excessive calculation time. If the 2-D mesh is satisfactory, 3-D mesh generation can be performed. The 3-D mesh generation process takes the information from the work planes at different levels as well as the soil stratigraphy from the boreholes into account. The basic soil elements of a 3-D finite element mesh are the 15-node 
wedge elements as shown in Fig 8. These elements are generated from the 6-node triangular elements as generated in the 2-D mesh. Due to the presence of non-horizontal soil layers, some 15node wedge elements may degenerate into 13-node pyramid elements or even into 10-node

tetrahedral elements. (Brinkgreve et al., 2007). The remaining part of the geometry has a medium element distribution 3-D mesh, shown in Fig 9, 10.

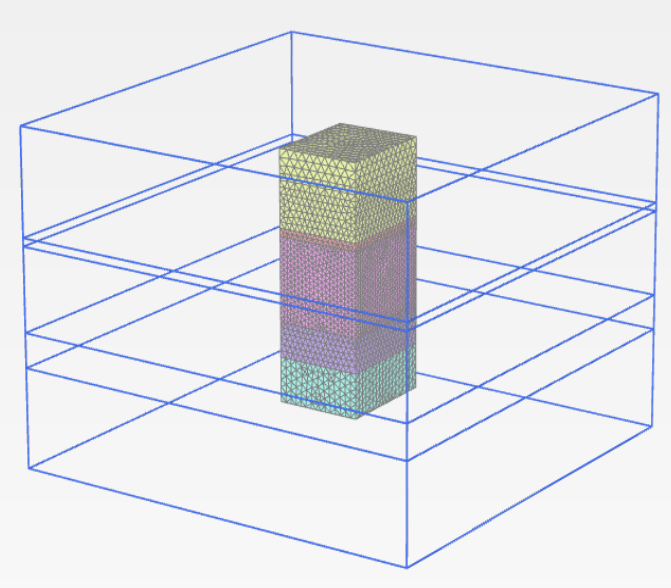

Fig 7 volume surrounding pile with refined mesh

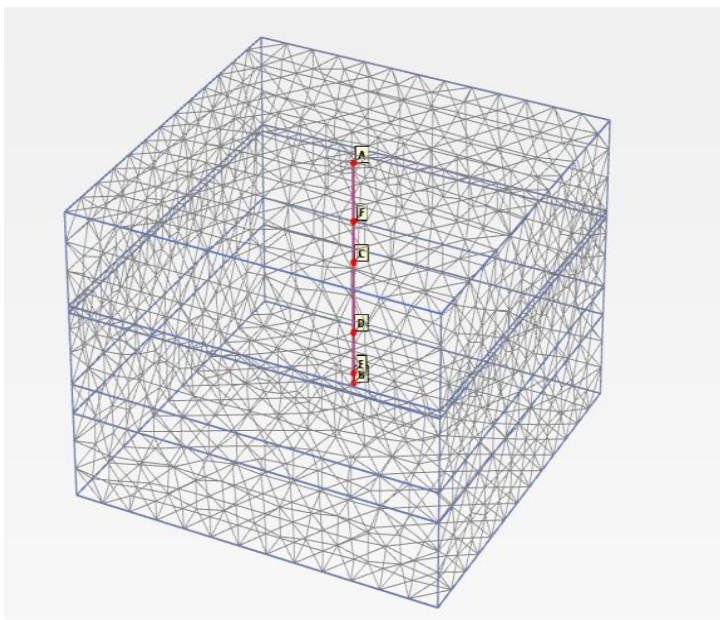

Fig9: Show point with the embedded pile model

\section{LOADING}

Based on the field study which is referred to the paper with the title "Field Test and Numerical Analysis of Monopiles for Offshore Wind Turbine Foundation" Pan et al. (2016), explained the following item.

\subsection{Vertical Loading Tests}

To conduct static vertical loading and unloading tests on piles S1 and S2-such as that shown in Fig. 11-a 50,000 kN counter force beam system was used. The vertical loading system involves 16 fluid pressure jacks $(5,000 \mathrm{kN}$ capacity), a circuit, and a pump with $70 \mathrm{MPa}$ ultra-high pressure. Test data is collected by the static test system. Loading and unloading were controlled by an accurate 
indicator. The vertical load started at $8,000 \mathrm{kN}$ and was increased in stages of 4,000 kN, reaching $50,000 \mathrm{kN}$. In PLAXIS3-D, the vertical load started at $8000 \mathrm{kN}$ and was increased in stages of 4000 $\mathrm{kN}$ to reach the maximum load of $50000 \mathrm{kN}$ as well.

\subsection{Horizontal Loading Tests}

The horizontal loading system had a $1,000 \mathrm{kN}$ counter force beam system, a horizontal hydraulic jack (600 kN capacity), a circuit, and a pump with $70 \mathrm{MPa}$ ultra-high pressure. Fig. 12. Horizontal loading and unloading were controlled by the pressure sensor. The pile top was reinforced prior to the horizontal pile loading test. The horizontal loading test started at $100 \mathrm{kN}$ with an increment of $50 \mathrm{kN}$ for each loading stage until the maximum horizontal load was $500 \mathrm{kN}$. In PLAXIS 3-D, the horizontal loading test started at $100 \mathrm{kN}$ with an increment of $50 \mathrm{kN}$ for each loading stage to reach the maximum load of $500 \mathrm{kN}$.

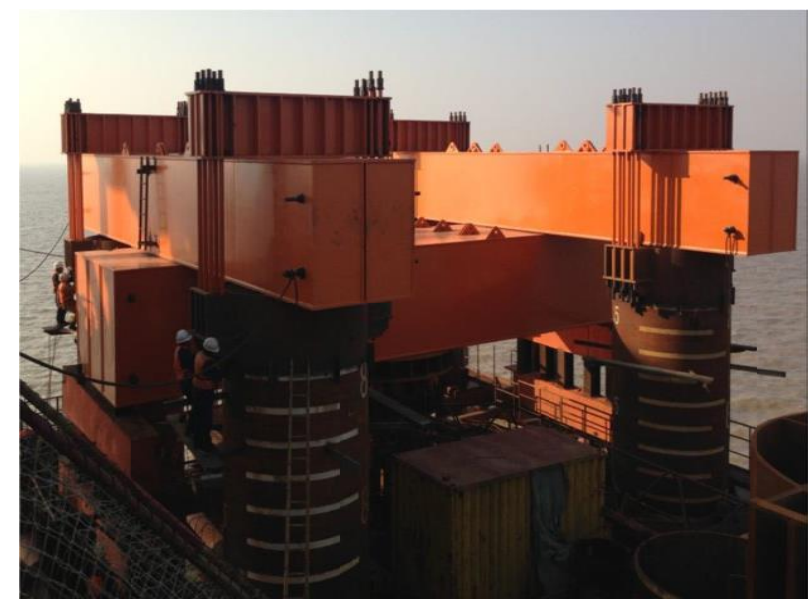

Fig11: Vertical loading system (Pan et al, 2016).

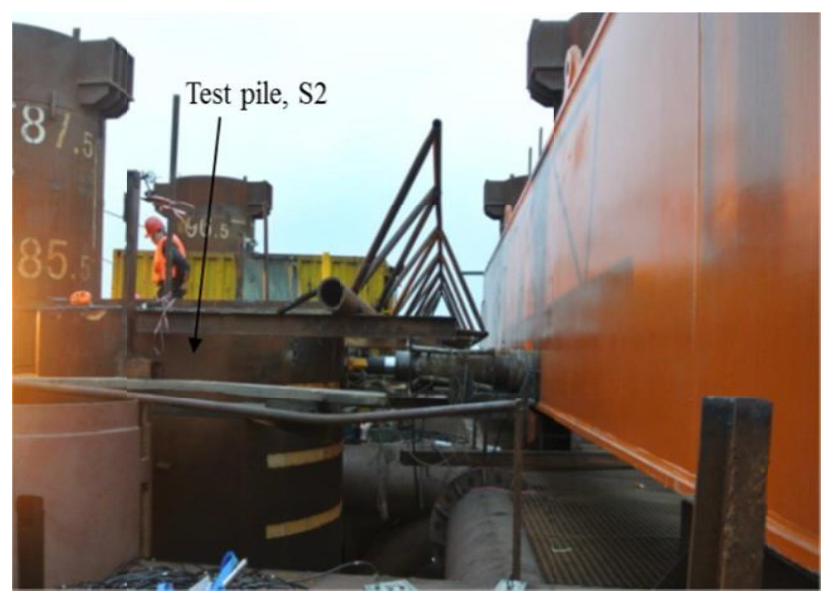

Fig12: Horizontal loading system (Pan et al, 2016).

\section{RESULTS}

\subsection{The Vertical Load}

Fig. 13 shows the results of pile top and tip displacement in the vertical loading test, compared with the results of the three-dimensional finite-difference program FLAC 3-D, and the three-dimensional finite element program PLAXIS 3-D. The field results show that the pile top settlement increases linearly with vertical load. The maximum settlement was $46 \mathrm{~mm}$ at 50,000 kN. During unloading, the pile top displacement also decreases linearly. There was a $6 \mathrm{~mm}$ residual pile top settlement after unloading. The three-dimensional finite-difference program FLAC 3-D results show that pile top displacement from the back-analysis increased with increasing vertical load with a slight nonlinear stiffness effect. The maximum settlement was $53 \mathrm{~mm}$ at $50,000 \mathrm{kN}$. During unloading, the pile top displacement also decreased linearly. There was a $4 \mathrm{~mm}$ residual pile displacement, PLAXIS 3-D shows the pile head displacement from the back-analysis increased for vertical load with a small non-linear stiffness effect. The maximum settlement was $59 \mathrm{~mm}$ at $50,000 \mathrm{kN}$. The pile top settlement from the numerical back-analysis is slightly larger than that from the field data but close to the results of FLAC 3-D. During unloading, the pile head displacement also decreased linearly. There was a $7 \mathrm{~mm}$ residual pile displacement which is close to the field result $(6 \mathrm{~mm})$. 
Table (4) shows a summary of pile top max settlement, pile top settlement after unloading, and the percentage value of residual settlement from the max settlement between the results of software programs (PLAXIS 3-D, FLAC 3-D) and field test results.

Table4: Summary of compared Pile top settlement of program (PLAXIS 3-D, FLAC3-D) and field test results

\begin{tabular}{|c|l|l|l|}
\hline results & Field tests & PLAXIS 3-D & FLAC 3-D \\
\hline Pile top max settlement (mm) & $\mathbf{4 6}$ & $\mathbf{5 9}$ & $\mathbf{5 3}$ \\
\hline $\begin{array}{c}\text { Residual pile top settlement } \\
\text { after unloading (mm) }\end{array}$ & $\mathbf{6}$ & $\mathbf{7}$ & $\mathbf{4}$ \\
\hline $\begin{array}{c}\text { Residual settlement / max } \\
\text { settlement }(\%)\end{array}$ & $\mathbf{1 3}$ & $\mathbf{1 2}$ & $\mathbf{8}$ \\
\hline
\end{tabular}

The field results show that the pile tip settlement increases linearly with the increase of vertical load. The maximum tip settlement was $9.6 \mathrm{~mm}$ at 50,000 $\mathrm{kN}$. During unloading, the pile tip displacement also decreased linearly and the pile tip residual settlement was $4.5 \mathrm{~mm}$. FLAC3D results show that the pile tip settlement increased linearly with the vertical load. The maximum tip settlement was $6 \mathrm{~mm}$ at 50,000 $\mathrm{kN}$. During unloading, the pile tip displacement also decreased linearly and the pile tip residual settlement was $5 \mathrm{~mm}$. In PLAXIS3D, pile tip settlement increased linearly with the vertical load. The maximum tip settlement was $9.5 \mathrm{~mm}$ at 50,000 kN. During unloading, the pile tip displacement also decreased linearly and the pile tip residual settlement was $5 \mathrm{~mm}$. The pile tip settlement and the tip residual settlement results from the back analysis of PLAXIS3D have a similar profile to the field data results. The linear relationship between the pile settlement and the vertical load indicates that the soil surrounding the pile was still mostly in an elastic state and $50,000 \mathrm{kN}$ is probably still far from the vertical ultimate pile capacity. Table 5 below illustrates a summary of compared pile tip max settlement, pile tip settlement after unloading, and the percentage residual settlement from max settlement between the results of software programs (PLAXIS3D, FLAC3D) and field test results.

Table5: comparison between Field Test settlements at pile tip and Numerically Predicted Results

\begin{tabular}{|c|l|l|l|}
\hline results & Field tests & PLAXIS3D & FLAC3D \\
\hline Pile tip max settlement (mm) & $\mathbf{9 . 6}$ & $\mathbf{9 . 5}$ & $\mathbf{6}$ \\
\hline $\begin{array}{c}\text { Residual pile tip settlement after } \\
\text { unloading (mm) }\end{array}$ & $\mathbf{4 . 5}$ & $\mathbf{5}$ & $\mathbf{. 5}$ \\
\hline $\begin{array}{c}\text { Residual settlement / max } \\
\text { settlement }(\%)\end{array}$ & $\mathbf{4 7}$ & $\mathbf{5 2}$ & $\mathbf{8}$ \\
\hline
\end{tabular}

\subsection{Axial force}

In the field test, as the strain in the steel pile was monitored by optical fiber sensors, the pile axial force distribution could be calculated at each load stage. In the numerical analysis, the pile axial force was found to decrease with the embedded pile depth from the sea bed elevation level (-13.5 $\mathrm{m})$. There are several stages of loading that affect the pile axial force. For this result, only a few particular stages can be utilized to compare with the pile test because the loading procedure has been simplified in numerical analysis. Some specific stages were used to compare with pile tests, e.g., 20,000 kN, 40,000 kN, and 50,000 kN stages. The pile axial results from PLAXIS 3-D agree well with the results of FLAC 3-D and the pile test results as shown in Fig. 14. 


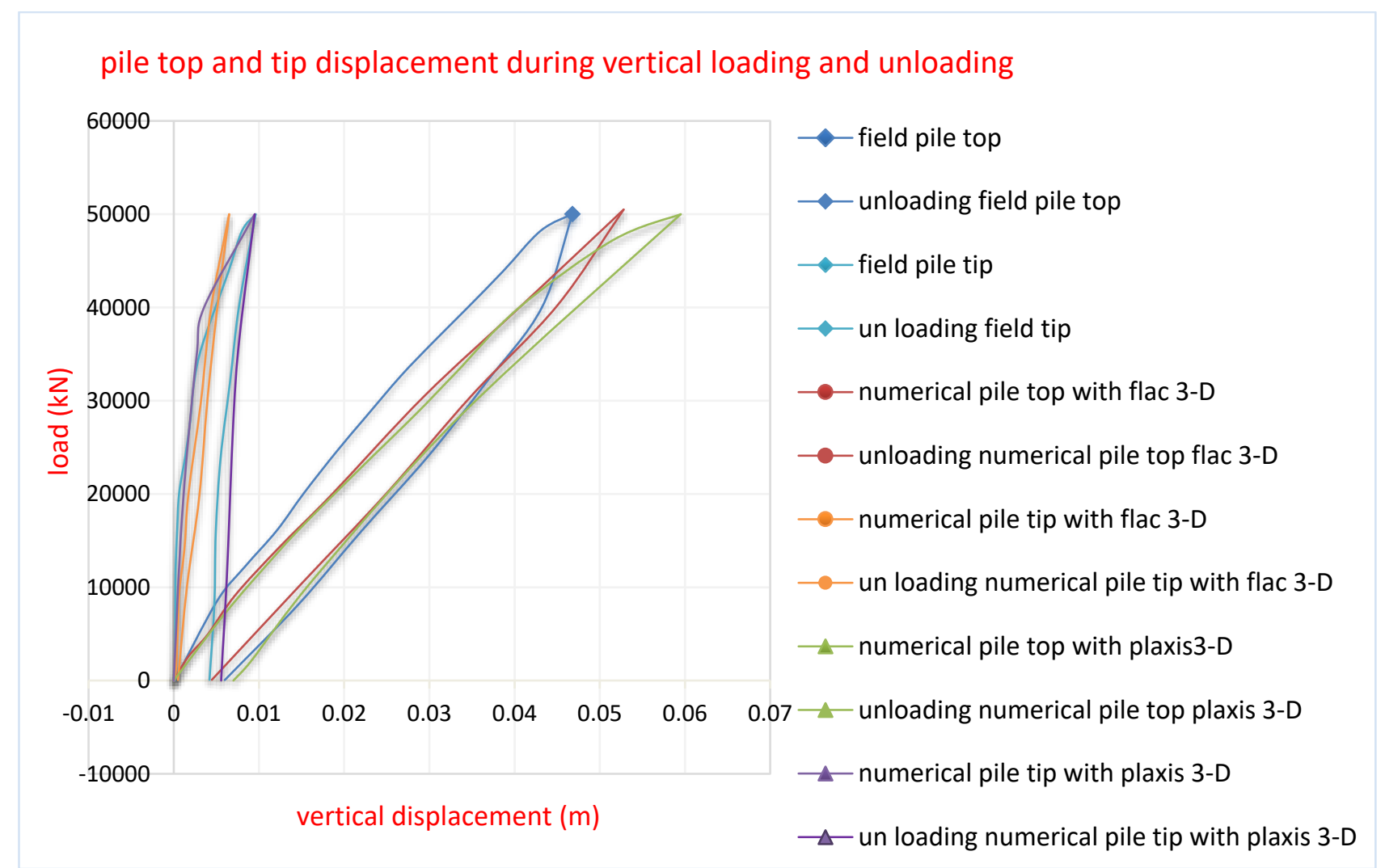

Fig. 13: the comparison results of pile top and tip displacement during vertical loading and unloading

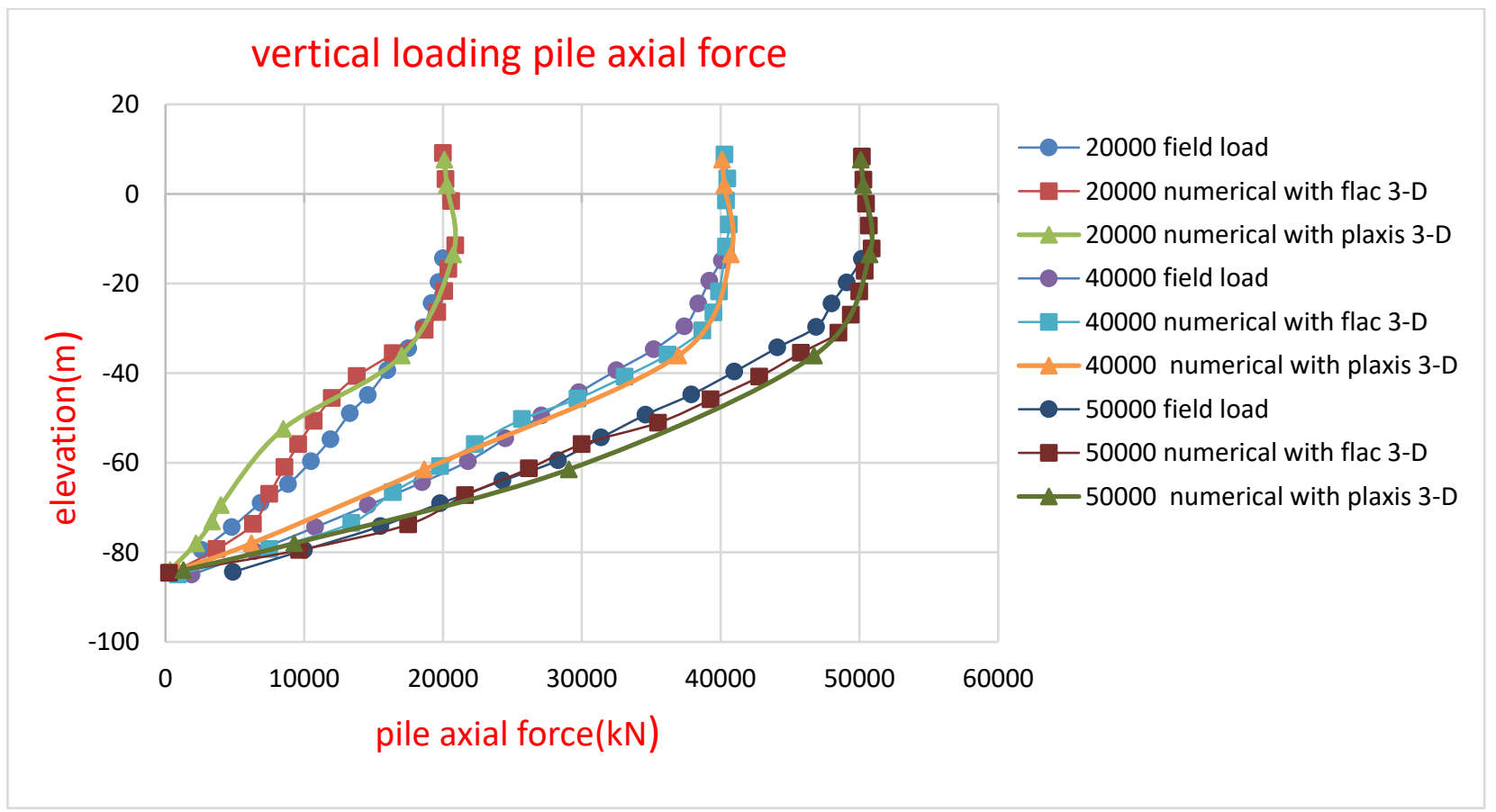

Fig. 14: the comparison results of pile axial force during vertical loading 


\subsection{The horizontal load}

Fig. 15 shows pile horizontal displacement at load point and that at the mud line (line of demarcation between fairly supernatant water and soil under sea level) compared with the predicted results by the horizontal loading tests, FLAC 3-D, and PLAXIS 3-D which show the results of lateral displacement of the pile profile of the field data are similar with the results of PLAXIS3-D program. In the field, the pile head horizontal displacement increases with decreasing stiffness and with increasing horizontal load. Table 6 illustrates a summary of compared field test results pile maximum displacement at pile head and mudline level under maximum load of $500 \mathrm{kN}$ compared with the results of programs (PLAXIS 3-D, FLAC 3-D). The embedded part of the pile is stiff with soil which is called soil-pile interaction and it is different from the free part of the pile above the mudline, for which resistance depends only on the dimensions of the pile. Therefore, as the results showed, the maximum lateral displacement at point load is about 10 times that at pile mudline.

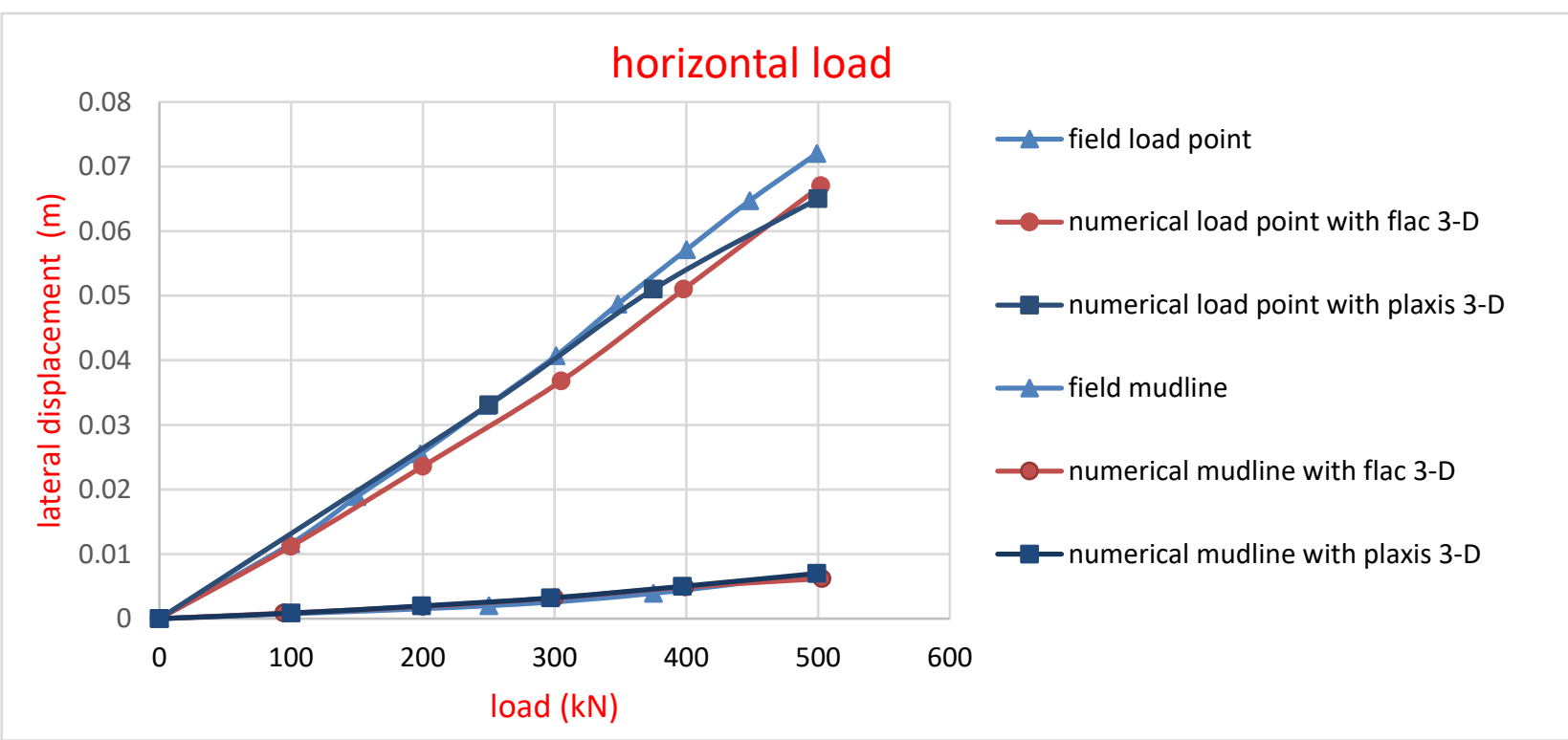

Fig. 15: the comparison results of pile top displacement during horizontal loading

Table6: compared Pile max displacement at head pile and mudline level of program and field test results

\begin{tabular}{|c|l|l|l|}
\hline results & Field tests & PLAXIS3D & FLAC3D \\
\hline max displacement $(\mathrm{mm})$ & $\mathbf{7 3}$ & $\mathbf{6 6}$ & $\mathbf{6 7}$ \\
\hline $\begin{array}{c}\text { max displacement at } \\
\text { mudline }(\mathrm{mm})\end{array}$ & $\mathbf{7}$ & $\mathbf{6 . 9}$ & $\mathbf{6 . 2}$ \\
\hline
\end{tabular}

The pile horizontal displacement and bending moment were derived from the field data below the sea bed level at different horizontal load stages from $100 \mathrm{KN}$ to $500 \mathrm{KN}$ of load. The $400 \mathrm{KN}$ horizontal load test stage can be used to compare pile displacement and bending moments in the horizontal loading test with FLAC 3-D and PLAXIS 3-D. Figures 16 and 17 show that the results of pile horizontal displacement and bending moment of the numerical analysis of program PLAXIS 3 -D at a load of $400 \mathrm{KN}$ are similar to the pile test results and close to the results of program FLAC 3-D. 


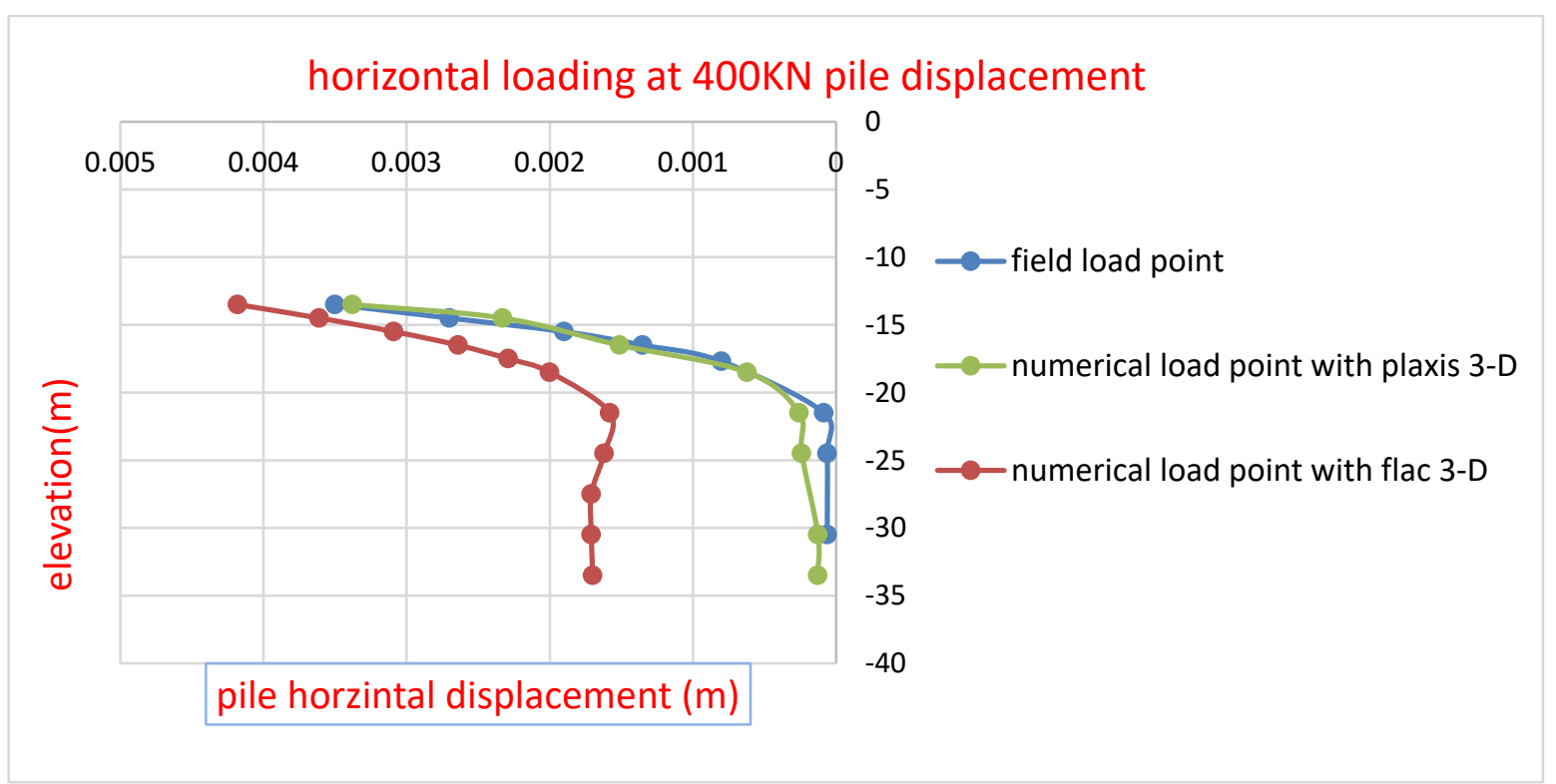

Fig. 16: the comparison results of pile displacement at 400kn during horizontal loading stage

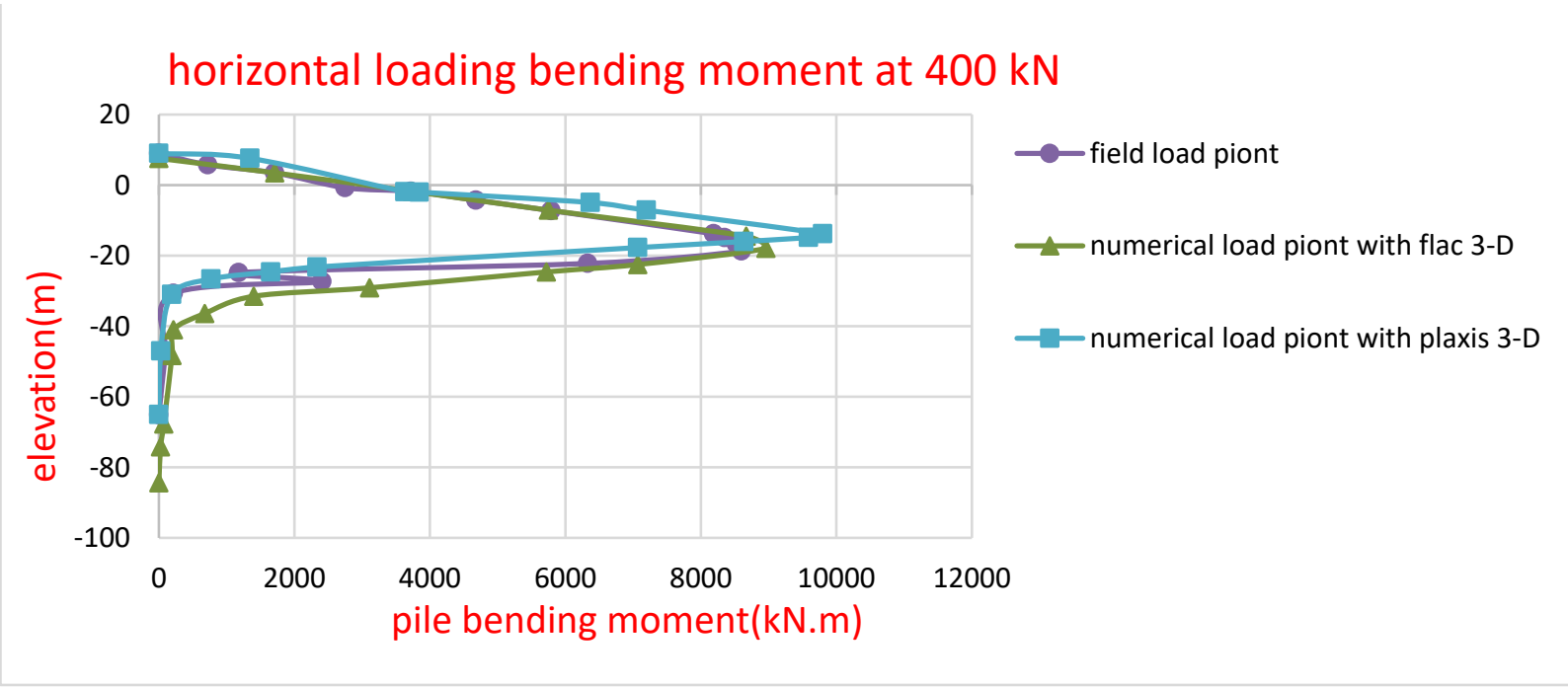

Fig. 17: the comparison results of bending moment at $400 \mathrm{kn}$ during horizontal loading stage

\section{NOTATION}

Ç Effective cohesion of shearing resistance for the soil

$\Phi$ Effective angle of shearing resistance for the soil

$\gamma$ Bulk unit weight of soil

U Poisson ratio

$\mathrm{E}_{\mathrm{p}}$ Young's modulus of the pile

Ês Young's modulus of the soil for small strain

\section{SUMMARY AND CONCLUSIONS}

This paper presents the validation of a three-dimensional finite element model using PLAXIS3D for field tests on monopile foundations for offshore wind turbines subjected to vertical and 
horizontal load. Numerical simulations were conducted using the Mohr - Columb model for the soils, and embedded pile elements for the monopiles. PLAXIS 3D finite elements simulation was

compared to field measurements of the instrumented full-scale field loading test as well as finitedifference simulation using FLAC3D. The following summarizes the findings of this investigation.

- For vertical loading tests, there was a good agreement between the results of the pile settlement (tip and top) and axial forces for loading and unloading stages between numerical simulations using the program PLAXIS3D, field load test results, and the results of FLAC3D.

- PLAXIS3D provided results that were closer to the field test results, with similarity of about (90\%-92\%) compared to FLAC3D, whose similarity is about (25\%-60\%) in terms of the percentage of residual settlement from the maximum settlement at pile tip and top.

- For horizontal loading tests, the results of pile head and mudline displacements from PLAXIS3D have a similar profile to that of the pile test results. The percentage of similarity is about $95 \%$, which is close to the results of FLAC3D.

- The results of the pile horizontal displacement and the bending moment of the numerical analysis of PLAXIS 3-D at a load of $400 \mathrm{KN}$ are similar to the pile test results with a percentage of $95 \%$ and better than the results of FLAC3D.

- The simulation shows that the PLAXIS 3D model gave similar results to field test measurements, so it is considered a reliable model for the simulation of monopile foundations under different load modes.

\section{REFERENCES}

Arulanantham, J., \& Eng, B. (2015), "3-D finite element analysis of laterally loaded short shafts in soil", Doctoral Dissertation, Ryerson University, Canada.

Bekken, L. (2009): Lateral behavior of large diameter offshore monopile foundations for wind turbines Doctoral dissertation, TU Delft, Delft University of Technology

Brinkgreve, R. B. J., Broere, W., \& Waterman, D. (2007), "Plaxis 3D-foundation reference manual, Version 2", Plaxis, Netherlands.

Brinkgreve, R. B. J., Kumarswamy, S., Swolfs, W. M., Waterman, D., Chesaru, A., \& Bonnier, P. G. (2016). "PLAXIS 2016", PLAXIS, Netherlands.

Cabral, A. (2015). "Diameter effects of large scale monopiles", Master Thesis, University of Portugal, Portugal.

Carswell (2012), W.: Probabilistic analysis of offshore wind turbine soil-structure interaction. Doctoral dissertation, University of Massachusetts Amherst.

Dao, T. P. T. (2011), "Validation of PLAXIS embedded piles for lateral loading", Ph.D. Dissertation, TU Delft, Delft University of Technology.

EWEA (2015), "The European offshore wind industry key trends and statistics 1st half 2015", European Wind Energy Association (EWEA), 1, 8.

Fausett, L. V. (2003), "Numerical methods: algorithms and applications", a book published in Upper Saddle River, NJ.

El-Marassi, M. A. (2011). Investigation of Hybrid Monopile - Footing Foundation Systems Subjected to Combined Loading. September.

Malhotra, S. (2011), "Selection, design and construction of offshore wind turbine foundations", INTECH Open Access Publisher. 
Pan, D., Lucarelli, A., \& Cheng, Z. (2016), "Field test and numerical analysis of monopiles for offshore wind turbine foundations", Proceedings of the Geotechnical and Structural Engineering Congress 2016 (pp. 1138-1152).

Tibebu, G. (2020), "Three-dimensional finite element analysis of laterally loaded Single Passive Pile in Sandy Soils", Master thesis, MA: University of Addis Ababa

Zienkiewicz, O.C.and Cheung, Y.K. (1965), "Finite Elements in the Solution of Field Problems", the Engineer, September 24th.

Leite, O. B. (2015). Review of Design Procedures for Monopile Offshore Wind Structures. 146. 